\title{
Survival and infectivity studies of in-vitro cultivated larvae of Haemonchus contortus in Sheep and Goats in Nigeria
}

\author{
A O Sonibare*, H A Kumshe, E A Okewole, A 0 Talabi, O. O. Alaka, E B Otesile, R A J oshua \\ 1 Department of Veterinary Medicine and Surgery, University of Agriculture Abeokuta, Ogun \\ state Nigeria. 2 Faculty of Veterinary Medicine University of I badan, I badan Oyo state Nigeria \\ 3 Department of Veterinary Medicine University of Maiduguri, Maiduguri Borno state, Nigeria \\ * Corresponding author email: ayo sike@yahoo.com \\ Received: 27-05-2011, Accepted: 16-06-2011, Published Online: 23-10-2011
}

doi: $10.5455 /$ vetworld.2011.533-536

\begin{abstract}
The survival and infectivity of indigenous isolates of Haemonchus contortus and in vitro cultivated infective larvae $\left(\mathrm{L}_{3}\right)$ were studied. Active motile gravid females, adult and immature parasites were morphologically and morphometrically characterized and isolated from Haemonchus infected goats. These were subsequently inoculated into the abomasum of parasite free lambs through left sided laparatomy for production of fertile eggs to be used for coproculture. Harvested faeces from these lambs were cultured in a nutritive medium and kept in the incubator at $32^{\circ} \mathrm{C}$ and room temperature $24-28^{\circ} \mathrm{C}$ to obtain in vitro cultivated $\mathrm{L}_{3}$ of $H$. contortus. The infectivity and survival of in vitro cultivated $\mathrm{L}_{3}$ stored in refrigerator at $4-8^{\circ} \mathrm{C}$ and under room temperature $24-28^{\circ} \mathrm{C}$ were evaluated. Incubation period of coproculture was observed to be shorter in medium at $32^{\circ} \mathrm{C}$ than under room temperature $24-28^{\circ} \mathrm{C}$. The storage of in vitro cultivated $\mathrm{L}_{3}$ under different temperature range showed that the quantity of active larvae in a given volume decreased at $\mathrm{p}<0.05$ from the $5^{\text {th }}$ day under $24-28^{\circ} \mathrm{C}$ while at $4-8^{0} \mathrm{C}$ became significantly lower from $20^{\text {th }}$ day. Infectivity of isolate kept at $4-8^{0} \mathrm{C}$ was sustained for $18-20$ days while at $24-28^{\circ} \mathrm{C}$ it was maintained for $10-12$ days. Laboratory invitro cultivated $\mathrm{L}_{3}$ of $H$. contortus had limited infectivity and larvae mortality increase with time under different temperatures.
\end{abstract}

Key words: Indigenous goats, Haemonchus contortus, In-vitro cultivated $\mathrm{L}_{3}$, storage, survival and infectivity

\section{I ntroduction}

Gastrointestinal parasitism had been identified as a complex disease constituting a major impediment to efficient and profitable livestock production particularly among sheep and goats all over the world (Baker et al., 1999, Chiezey et al., 2008).

Among various intestinal parasites $H$. contortus $i$ s the most important and it is responsible for most field outbreaks of acute and sub acute parasitic gastroenteritis of small ruminants (Fakae et al., 1999, 2004). The potential use of vaccines as a means of controlling gastro intestinal parasitic infection appears to be a promising and viable option (Bowels et al., 1995, Chiejina et al., 2002, Meeusen and Piedrafita 2003, Newton and Meeusen, 2003). Previous studies on $H$. contortus have shown that pathogenicity and infectivity of various strains varied from one location to the other (Yadav et al., 1993, Waruiru et al., 1994). This study was designed to isolate and characterize the local strain of $H$ contortus in various goat breeds found in Nigeria. The survival and infectivity of in vitro cultivated larvae from local strain are to be assessed as a prelude to determining their immunogenicity and usefulness as candidate vaccine in the future.

\section{Materials and Methods}

Experimental animals and their management: Two (2) male lambs aged 6-7 months old and five (5) West African Dwarf (WAD) kids (6-8 months) were sourced from markets and house-hold keepers in rural areas in the outskirts of Abeokuta. The ethics committee of the college of veterinary medicine university of Abeokuta approved the study. The experiment was carried out in a goat house belonging to the College of Veterinary Medicine, University of Agriculture Alabata, Abeokuta, Ogun state, Nigeria. Alabata lies at $7^{0} 10 \mathrm{~N}$ and $3^{\circ} 2 \mathrm{E}$. It has a prevailing tropical climate with mean annual rainfall of about $1037 \mathrm{~mm}$. The mean ambient temperature ranges from $28^{\circ} \mathrm{C}$ in December to $32^{\circ} \mathrm{C}$ in February with a yearly average humidity of about $82 \%$. The vegetation is an inter-phase between the tropical rain forest and derived savannah. 
These animals were kept in individual pens $\left(3 \frac{1}{2} \mathrm{ft}^{2}\right)$ with slatted floor and treated with Ivomec $^{\mathrm{R}}$ (Ivermectin $\left.0.02 \mathrm{mgkg}^{-1}\right)$, Coccidiostat $(200 \mathrm{mg}$ Trimethroprim and $100 \mathrm{mg}$ Sulphadiazine) by Chanelle Pharmaceuticals limited Spain, Provethrine $30^{\circledR}$ Cypermethrine 3\% (Panteck Holland. Berenil @ Diaminazine Aceturate $3.5 \mathrm{mgkg}^{-1}$ for the control of endoparasites, ectoparasites and haemoparasities. After acclimatization, animals were vaccinated with homologous Pests des Petites Ruminant vaccine (PPR) Vom, Jos, Nigeria. All experimental animals were fed with grasses, harvested from fields not previously grazed by any livestock and after harvest grasses were washed with $1 \%$ salt solution and sun dried before feeding (to take care of wild life helminth larvae). Tsetse fly traps were strategically located around the pen house.

Sourcing of $\mathbf{H}$. contortus, inoculation of lamb for multiplication: Fifteen abomasa were obtained from Bodija Municipal Goat Abbatoir, Ibadan Oyo state Nigeria. Five (5) from 3 breeds of Nigerian goats West African Dwarf (WAD), Red Sokoto (RS) and Sahel White (SW) goats heavily infested with Haemonchus Spp. Gravid adult and immature $H$. contortus were obtained from these abomasa and worms identified according to Soulsby, 1982, Hasen and Perry 1991 and Zajac, et al., 2006. These parasites were washed in a nutritive medium prepared as described by Hubert and kerbeouf 1992 (medium contained 5 $\mu$ l Amphotericine $\mathrm{B}$, which inhibits fungi growth), $1 \mathrm{gm}$ yeast extract in $90 \mathrm{ml}$ of normal saline solution 1:9 v/v (for nourishment of hatched larvae) and Earle's balance salt solution for electrolyte balance. Three hundred (300) very active gravid females, adult males and immature $H$. contortus were identified microscopically and were transferred into the 2 male lambs through left sided laparatomy. Thereafter the lambs were kept in isolation pen and fed on grasses harvested from field where livestock do not graze.

In-vitro cultivation of third stage infective larvae of $\mathbf{H}$. contortus $\left(\mathbf{L}_{3}\right)$ : Faeces harvested from inoculated lambs were processed using Baerman's technique by pooling the eggs of Haemonchus spp together, wrapped in Chinese cloth and submerged in nutritive medium solution in a funnel and the base was attached to a rubber tube to remove fluids. Ten (10) replica solution were made and five (5) of which were kept in an incubator at $32^{\circ} \mathrm{C}$ and remaining 5 (five) on the work bench at $24-28^{\circ} \mathrm{C}$ in the laboratory.

Estimation of larvae number, storage interval and antihelmintic susceptibility of isolate: The number of infective larvae in a given volume was estimated by taking $0.02 \mathrm{ml}$ of cultured medium solution and $0.001 \mathrm{ml}$ of tincture iodine. The addition of iodine immobilizes the infective larvae to enable accuracy in the counting. This process was repeated thrice and the average was taken for cultured medium stored at $4-8^{\circ} \mathrm{C}$ and $24-28^{\circ} \mathrm{C}$. The quantities of larvae in a given volume were evaluated on days $0,5,15$ and 20 . The solution containing the in-vitro cultivated infective larvae was kept in the refrigerator at $4-8^{\circ} \mathrm{c}$ and another kept on the work bench in the laboratory at room temperature of $24-28^{\circ} \mathrm{C}$. The infectivity of larvae in both storage methods were tested every two days to ascertain for how long the pathogenic strength can be sustained.

Five hundred (500) $\mathrm{L}_{3}$ obtained from culture medium was inoculated per os into 5 worm free WAD kids. Incubation period, clinical manifestation, harvesting of eggs (Faecal Egg Count), Packed Cell Volume (PCV) were monitored. This was to confirm establishment of the Haemonchus parasites. Dead experimental kids were necropsied for pathological changes and worm count while survival kids were consequently treated with Ivomec ${ }^{\circledR}$ (ivermectin $0.02 \mathrm{mgkg}^{-1}$ ) to ascertain that the Haemonchus worms isolated were not antihelmintic resistant.

\section{Results}

In vitro cultivation of third stage infective larvae of $\mathbf{H}$. contortus: The egg in cultured medium at $32^{\circ} \mathrm{C}$ in the incubator hatched into $3^{\text {rd }}$ stage infective larvae within 5-8 days while on the work bench at $24-28^{\circ} \mathrm{C}$ in the laboratory it took 14-19 days (figure I). The mean values of hatchability under different incubating temperatures were 11.33 and 11.88 under $32^{\circ} \mathrm{C}$ and 24 $28^{\circ} \mathrm{C}$ respectively. The comparisons of mean larvae count between two incubating temperatures using Ttest indicated no significant differences $(\mathrm{t}=0.43$, df $=10$ at $\mathrm{p}>0.05$ ).

Storage interval of in vitro cultivated larvae under different temperature: The quantity of larvae in a given volume was represented by the number of active larvae in field viewed under the microscope at $x 400$ objective. The quantity of active larvae in a given volume decreased over a period of time under both storage temperatures (Figure II). However larvae stored under $24-28^{\circ} \mathrm{C}$ became significantly lower at $\mathrm{p}<0.05$ from 5 day post storage while at $4-8^{\circ} \mathrm{C}$ a decrease with no significant difference ( $p>0.05)$ from day 0 to day 15 but became significantly decreased from day 20 post storage. The graphical representation of rate of decrease of larvae quantity showed an intersection at a point of storage 12 


\section{Fig.1 Hatchability count of in vitro cultivated larval} of Haemonchus contortious

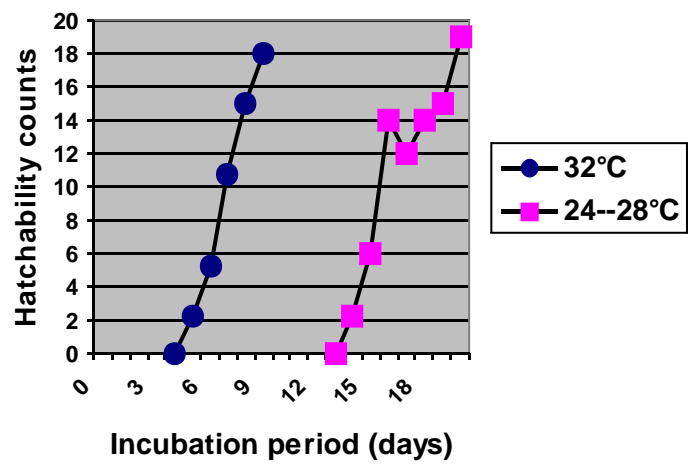

temperatures (Figure II). The interactions between the two storage temperatures revealed the same quantity of larvae at this intersection (16 active larvae at day 3 post storage). The storage of motile $3^{\text {rd }}$ stage larvae of Haemonchus contortus in the refrigerator at $4-8^{0} \mathrm{C}$ showed that larvae infectivity was maintained for 18 20 days. However storage at $24-28^{\circ} \mathrm{C}$ showed the infectivity was sustained for 10-12 days.

\section{Discussion}

Our observation of shorter incubation period at higher ambient temperature is consistent with earlier observations of Hansen and Perry 1991, Zajac et al., 2006 who reported variation in incubation periods of in-vitro cultivated larvae under different incubating temperatures. However Graber, 1975 Soulsby, 1982, Stankiewiez et al., 1996 reported that under natural environmental ambient temperature of $22-30^{\circ} \mathrm{C} H$. contortus eggs hatched to $\mathrm{L}_{3}$ within 4-5 days, these findings indicated existence of temperature dependent differences on the hatchability of Haemonchus eggs. It is in our thinking that current global changes in the climate and environmental temperature may have a direct bearing with the modification of the physiology and pathogenicity of these parasites.

Larvae assay in a given volume showed that the quantity of active larvae decreased as storage days increased and percentage decrease was temperature dependent (figure II). This finding indicated that larvae mortality increased with storage and the percentage mortality was temperature dependent. The observed influence of temperature on larvae assay and infectivity could be attributed to the fact that the lower temperature causes inactivation of larvae (Zajac et al., 2006) thus lesser utilization of available oxygen and nutrient in cultured medium leading to reduced
Fig.2 Effect of $s$ torage tem perature on in vitro cultivated larval counts of

$\mathrm{H}$ aem onchus contortus

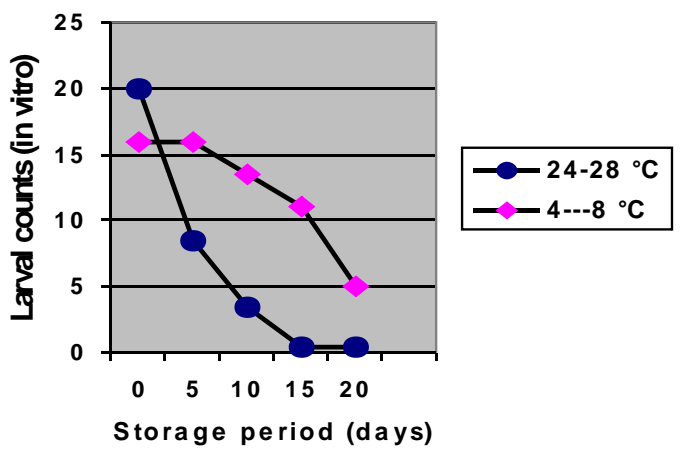

concentration of toxic metabolites. These factors may be responsible for the longevity of larvae and prolonged infectivity at lower temperature. The sharp decrease of $57 \%$ in larvae count stored under $24-28^{\circ} \mathrm{C}$ compared with $6 \%$ of $4-8^{0} \mathrm{C}$ stored larvae 5 days post storage (Figure II). The reasons for this drastic decrease at this $24-28^{\circ} \mathrm{C}$ temperature may also be in line with the explanation above owing to the fact that the more metabolically active parasites will exhaust the available nutrients and accumulate wastes more rapidly than the larvae at refrigeration temperature.

The time length of infectivity of 10-12 days observed in this study can be used to determine intervals of deworming animals in the field during strategic control of helminthiasis.

This observation showed the importance of locally sourced strain of nematodes as its gives a true reflection of infectivity as indicated in the microenvironment where these parasites are found.

By this study, it is proposed that in our search for a candidate vaccine for the control of haemonchosis in small ruminants, temperature variations may play a vital role in the modification of virulence/ pathogenicity of these parasites.

\section{Acknowledgements}

The authors wish to thank the authorities of the Federal University of Agriculture, Abeokuta Nigeria for partly sponsoring the work. The technical assistance of the staff of the laboratory of veterinary parasitology, College of Veterinary Medicine, University of Agriculture Abeokuta is highly appreciated.

\section{References}

1. Baker, R.L., Mwamachi, D.M., Audho, J.O., Aduda, E.O and Thorpe, E.W. (1999). Resistance of Galla and Small East 
African goats in the sub-humid tropics to gastrointestinal nematodes infections and peri-parturient rise in Faecal Egg Count. Vet. Parasitol. 79: Pp 53-64.

2. Bowels, V.M., Brandson, M.R and Meeusen, E (1995). Characterization of local antibody responses to the gastro intestinal parasites Haemonchus contortus. Immunology. 84: Pp 669-674.

3. Chiejina, S.N., Fakae, B.B., Behnke O., Nnadi, P.A., Musongoag, G.A. and Wakelin, D. (2002) Expression of acquired immunity to local isolate of Haemonchus contortus by the Nigeria West African Dwarf goats. Veterinary Parasitology. 2271: Pp 1-14.

4. Chiezey, N.O.; Aganubi, O.J. and Oyedipe, E.O. (2008). The reproduction performance of sheep carrying natural infection of gastro-intestinal nematodes. Asia Journal of Animal and Veterinary Advances. 3(4): Pp 236-243.

5. Fakae, B.B., Chiejina, S.N. Behnke, J.M. Ezeokonkwo, R.C., Nmadi, P.A., Onyenwe, W.I., Gilbert, F.S. and Wakelin, D. (1999). The response of Nigeria West African Dwarf goats to experimental infection with Haemonchus contortus. Veterinary Science. 113: Pp 147-158.

6. Fakae, B.B. Musongong, G.A. Chiejina, S.N., Behnke, J.M., Ngongeh, L.A. and Wakelin, D (2004). Variability in the resistance of the Nigeria West African Dwarf goats to abbreviated escalating trickle and challenge infections with Haemonchus contortus. Vet parsitology. 122: Pp 51-65.

7. Hasen, J. and Perry, B. (1990). The epidemiology and control of helminth parasites of ruminants. A handbook international laboratory for research in animal diseases.
ILRAD, Nairobi, Kenya. Pp 171.

8. Hubert, J. and Kerboeuf, D. (1992). A microbial development assay for the detection of antihelmintic resistance in sheep nematodes. Vet Rec. 130: pp 142-146.

9. Meesuen, Els. N.T. and Piedrafita, D. (2003) Exploiting natural immunity to helminth parasites for the development of veterinary vaccines. Inter. Jour. for. Parasit. 33: Pp 12851290.

10. Newton, S.E. and Meesuen, E.N.T (2003). Progress and New technology for developing vaccine against gastrointestinal nematodes parasites of sheep. Parasite Immunology. 25: Pp 283-296.

11. Stankiewiez, M., Cabaj, W., Pernthaner, W., Jonas, W., Rabel, B., (1996). Drug abbreviated infection and development of immunity against Trichostrongylus colubriformis in sheep. Int. J. Parasitol. 26. Pp 97-103.

12. Soulsby, E.J.L. (1982). Helminth, Athropods and Protozoa of domesticated animals. $7^{\text {th }}$ ed. Bailliere Tindall, London U.K., Xi Pp 809.

13. Waruiru, R.M., Karanu, F. N., Ruvuna, F. Gichanga, E. J. Taylor, D.J., Jasmer, D., Rurangirwa, F. and Mcguire, T.C. (1994). Differential resistance among goats to ;primary and secondary challenges of Haemonchus contortus. Bull. Anim. Hlth. Pro. Afri. 42: Pp 193-197.

14. Yadav, C.L., Grewal, H.S., and Banerjee, D.P., (1993). Susceptibility of Two cross breeds of sheep to Haemonchus contortus. Int. J. Parasitol. 23: 819-822.

15. Zajac, M. Anne and Garya Cpnboy (2006) Veterinary Clinical Parasitology, $7^{\text {th }}$ ed. Blackwell Publishing Co.UK. 